\title{
Nutritional, physical and sensory properties of high protein gluten and egg-free cookies made with resistant starch type 3 Maranta arundinaceae flour and flaxseed
}

\author{
${ }^{1 *}$ Nugraheni, M., ${ }^{2}$ Sutopo, ${ }^{1}$ Purwanti, S. And ${ }^{1}$ Handayani, T.H.W. \\ ${ }^{1}$ Department of Culinary Art Education, Yogyakarta State University, Depok Sleman, Yogyakarta, 55281 \\ ${ }^{2}$ Department of Mechanical engineering Education, Yogyakarta State University, Depok, Sleman, \\ Yogyakarta, 55281
}

\author{
Article history: \\ Received: 4 April 2019 \\ Received in revised form: 15 \\ May 2019 \\ Accepted: 16 May 2019 \\ Available Online: 24 May \\ 2019
}

Keywords:

Cookies,

High protein,

Gluten and egg-free,

Maranta arundinaceae,

Flaxseed

DOI:

https://doi.org/10.26656/fr.2017.3(6).145

\begin{abstract}
This research was aimed to study on the nutritional, physical and sensory properties of the developed high protein gluten and egg-free cookies made with resistant starch type 3 (RS3) Maranta arundinaceae flour and flaxseed as egg replacer. The research method was done by examining the different cookies formulations based on the amount of RS3 $M$. arundinaceae flour. Cookies made with wheat flour was used as control. Proximate analysis, resistant starch and dietary fiber analysis were used to evaluate the nutritional properties of the developed cookies while the physical properties were evaluated based on the spread ratio and texture analysis. The outcome of this research had proved that cookies made with $10 \%$ RS3 M. arundinaceae flour was highly accepted with an overall acceptance score of $7.56 \pm 0.63$ from the sensory evaluation. The cookies also had the following nutritional properties: $16.84 \pm 0.10 \%$ protein content; $18.94 \pm 0.09 \%$ dietary fiber; and $2.81 \pm 0.17 \%$ resistant starch levels along with the following physical proerties: $8.34 \pm 0.23$ spread ratio and $13.67 \pm 0.22$ texture. The developed cookies will be beneficial to those who are sensitive to gluten and/or eggs.
\end{abstract}

\section{Introduction}

Cookies are associated as the source of energy and are a product that is ready to be consumed. Moreover, cookies can also be produced in high numbers with a short time, and it is easy to be widely distributed (Zucco et al., 2011). Indonesia has the abundance of food sources, i.e. tubers, legumes, cereals which can be used as a constituent of the development of gluten-free flour for making cookies. According to SNI 01-2973-1992, cookies are one of the types of biscuits made from soft dough, containing high fat, relatively crisp when broken and densely textured. According to Mamat and Hill (2014), fat in cookies serves as shortening which affects the texture, flavor, tenderness, and mouthfeel. The essential ingredients of making cookies consist of flour with protein, fat, sugar, and eggs.

The development of gluten-free cookies is currently required in line with the growing demand for functional foods that can minimize the occurrence of allergies to constituents such as gluten and eggs (Barros and Cosme, 2013). Gluten-free food products also have benefits to reduce the risk of type 1 diabetes mellitus (Filbert and Sein, 2013). Wheat flour which is high in gluten is commercially used for the production of cookies and this can be an issue for people who are allergic to gluten (Boettcher and Crowe, 2013).

The use of different food such as tubers, legumes and cereals as a source of carbohydrate is possible for patients with diabetes mellitus. However, there is a need to attempt the modifications in the processing to increase the levels of resistant starch (Alcazar-alay and Meireles, 2015). This is because, resistant starch can provide a positive impact on the management of the lipid and glucose profile in diabetics mellitus and improve insulin sensitivity for a better management of diabetes mellitus type 2 (Robertson et al., 2005). Resistant starch can be produced by the autoclaving-cooling process which increased the levels of RS3 in carbohydrate materials (Lilia-Baby et al., 2016).

High protein gluten and egg-free cookies made with RS3 of M. arundinaceae flour is a new product that has a composition of different constituent materials from wheat flour made cookies that are currently sold to consumers. The difference in the composition of material may affect the characteristics of the cookies, in terms of the nutrients, physical properties, but also sensory 
properties. The development efforts of commercialization of high protein gluten-free cookies enriched with RS3 into functional food must be supported with clear information of the nutrition, physical and sensory properties. So, it is necessary to research on the formulation impact of the developed RS3 high protein gluten-free cookies.

This study is aimed to determine the characteristics of nutritional, physical and sensory properties of the high protein gluten and egg-free cookies made with RS3 $M$. arundinaceae flour and flaxseed as an egg replacer.

\section{Materials and methods}

\subsection{Materials}

M. arundinaceae flour, brown rice flour, and soy flour obtained from local farmers in Clereng Kulon Progo, Yogyakarta, Indonesia. Tapioca flour, cornstarch, flaxseed obtained from commercial market in Yogyakarta, Indonesia. M. arundinaceae and Coleus tuberosus flour rich in RS3 was produced by 3-cycle autoclaving-cooling process (Mutiara et al., 2017).

\subsection{Formulation of cookies}

The cookies recipe was referred to the reference cookies recipe by Gisslen (2012) with little modifications (Table 1). Three formulations (FI, FII, and FIII) were concocted based on the different precentage of RS3 M. arundinaceae flour where FI used 10\%; FII used $12 \%$; FIII used 14\%.

Eggs were replaced with flaxseed. Some $10 \mathrm{~g}$ flaxseed was added $45 \mathrm{~mL}$ water and stirred. It was allowed to sit in the refrigerator for 15 mins to complete the gel making process. The other constituents of the cookies were stirred and mixed evenly with the flaxseed gel. Then, the high protein gluten-free flour (composition can be referred in Table 1) was folded in with cocoa and cheese. Cookies were shaped and baked in the top bottom heating oven (Top: $120^{\circ} \mathrm{C}$; Bottom: $110^{\circ} \mathrm{C}$ ) for 40 mins.

\subsection{Nutritional analysis}

Proximate analysis, comprising of the moisture content, ash content, fat, protein and dietary fiber, were performed following AOAC methods (2005). The carbohydrate content was determined by difference. The resistant starch levels was determined by the methods of Englyst et al. (1992).

\subsection{Physical properties}

Cookies are taken at random and weighed using digital scales. The thickness (height) and the diameter of the cookies in triplicates was measured using a vernier caliper (Trickle brand, Shanghai China). Spread ratio was calculated dividing the diameter of the cookies with the thickness of the cookies (height) (Zoulias et al., 2000). The texture of the cookies was measured with Liyod universal testing machine type $1000 \mathrm{~S}$ within 24 hrs after the baking.

\subsection{Sensory evaluation}

The sensory evaluation was carried out by eighty people semi-trained panelists ( 30 men, 50 women) of students from the Culinary Art Education Department,

Table 1. Formulations of developed high protein gluten and egg-free cookies

\begin{tabular}{|c|c|c|c|c|}
\hline Ingredient & $\begin{array}{c}\text { Wheat flour cookies } \\
\text { as Control (g) }\end{array}$ & $\begin{array}{l}\text { High protein gluten and } \\
\text { egg-free cookies FI (g) }\end{array}$ & $\begin{array}{l}\text { High protein gluten and } \\
\text { egg-free cookies FII (g) }\end{array}$ & $\begin{array}{l}\text { High protein gluten and } \\
\text { egg-free cookies FIII (g) }\end{array}$ \\
\hline Wheat flour & 150 & - & - & - \\
\hline \multicolumn{5}{|c|}{ High protein gluten-free flour composition } \\
\hline Soy flour & & 48 & 48 & 48 \\
\hline Corn starch & & 19 & 19 & 19 \\
\hline M. arundinaceae flour & & 19 & 19 & 19 \\
\hline Tapioca flour & & 13 & 10 & 7 \\
\hline RS3 $M$. arundinaceae flour & & 15 & 18 & 20 \\
\hline RS3 C. tuberosus flour & & 1 & 1 & 1 \\
\hline Brown rice flour & & 35 & 35 & 35 \\
\hline Total amount of flour & 150 & 150 & 150 & 150 \\
\hline \multicolumn{5}{|l|}{ Other ingredients } \\
\hline Margarine & 90 & 90 & 90 & 90 \\
\hline Egg & 1 & & & \\
\hline Flaxseed & - & 10 & 10 & 10 \\
\hline Corn syrup & 15 & 15 & 15 & 15 \\
\hline Salt & 2 & 2 & 2 & 2 \\
\hline Cheddar cheese & 75 & 75 & 75 & 75 \\
\hline Chocolate powder & 5 & 5 & 5 & 5 \\
\hline Water & - & 45 & 45 & 45 \\
\hline
\end{tabular}


Yogyakarta State University. The evaluation was based on a 9-point hedonic scale: 1 (dislike extremely) and 9 (like extremely). The sensory evaluation was carried out on the four types of cookies baked after $24 \mathrm{hrs}$.

\subsection{Statistical analysis}

Data were analyzed with SPSS version 11.0 (Illinois, USA) using one-way analysis of variance (ANOVA) and LSD for significant difference at $\mathrm{p}<0.05$.

\section{Results and discussion}

\subsection{Nutritional analysis}

The nutritional composition of the four kind cookies made in this study, i.e., control cookies made from $100 \%$ wheat flour and three different formulations of high protein gluten and egg-free cookies are tabulated in Table 2. The role of the egg was replaced by flaxseed. Flaxseed is capable of forming a gel when mixed with water, the consistency of which is constructed like the consistency of egg (Uhlman and Schumacher, 2014) and have the functional compounds, such as $\alpha$-linolenic acid (ALA), dietary fiber and lignans (Hall et al., 2006).

The analysis showed that moisture content of the cookies ranged from $3.24-4.64 \%$, following the national standards Indonesia cookies (SNI 01-2973 2011) where the moisture content of freshly produced cookies should be under 5\% (Okaka, 2019). The moisture content influences the shelf life, appearance, texture, and taste of the food. Low water levels are expected to increase the shelf life of cookies. On the contrary, moisture content of cookies that are too low will produce burnt cookies. Whereas, if the moisture content is too high then the cookies produced are not crispy and will trigger the changes of flavor during storage (Manley, 2001).

The level of ash is a component that describes the levels of minerals in a given food. The higher value of ash content indicates the higher mineral content. The cookies had the ash content of $3.45-4.93 \%$. The levels of ash in the control cookies and high protein gluten-egg free cookies were highly alleged to be caused by components such as the flaxseed (3.4\%) (Ganorkar and Jain, 2013) and C. tuberosus flour (4.4\%) with the remaining constituents contributing to the different levels of ash. The fairly high-fat content in cookies was due to the margarine $(17 \%)$, the fat-containing flaxseed $(41 \%)$ (Ganorkar and Jain, 2013) and the cheddar cheese used as the ingredients. Nevertheless, the fat content of cookies met the Indonesia standard qualified quality pastries (cookies) according to SNI 01-2973-2011 where the minimum fat content of $9.50 \%$.

The protein content of high protein gluten and eggfree cookies was the highest $(16 \pm 0.10-17 \pm 0.27 \%)$ when compared with the control cookies $(15 \pm 0.05 \%)$. The protein content on the all purpose and high protein gluten -egg free cookies qualified the quality pastries (cookies) according to the standard national Indonesia SNI 0129732011 where the minimum protein levels by $5 \%$. According to Ciabotti et al. (2016), soy flour has a protein content of $35-39.80 \%$ which contributed to the high protein content. The carbohydrate levels of high protein gluten and egg-free cookies was the least than the control cookies (Table 2). The difference in the levels of carbohydrates was due to the existence of different content of protein, fat and total dietary fiber of the cookies.

The difference in the amount of RS3 $M$. arundinaceae flour gave an effect on the developed cookies. The levels of resistant starch in control cookies was the lowest compared to high protein gluten-egg free cookies. Resistant starch has a functional role whereby it not only lowers the amount of energy in food and improves the digestive function, but also improve the quality of bread (Witczak et al., 2016). Resistant starch can also improve the elasticity and porosity of bread (Tsatsaragkou et al., 2014). The content of insoluble fiber of the high protein gluten and egg-free cookies was more than soluble fiber (Table 2). The difference in the dietary fiber content could be due to the different dietary fiber of different flours used in the high protein glutenfree flour composition. Soy flour contained 6.70 $10.70 \%$ of dietary fiber (Ciabotti et al., 2016). Brown

Table 2. The nutritional properties of high protein gluten and egg-free cookies with flaxseed

\begin{tabular}{lcccc}
\hline \multirow{2}{*}{ Parameter } & \multirow{2}{*}{ Control } & \multicolumn{2}{c}{ High protein gluten-free cookies with flaxseed } \\
\cline { 3 - 5 } & & FI & FII & FIII \\
\hline Moisture & $3.88 \pm 0.07^{\mathrm{a}}$ & $4.64 \pm 0.08^{\mathrm{c}}$ & $4.60 \pm 0.03^{\mathrm{c}}$ & $3.69 \pm 0.07^{\mathrm{b}}$ \\
Ash & $3.45 \pm 0.07^{\mathrm{a}}$ & $4.93 \pm 0.04^{\mathrm{b}}$ & $4.69 \pm 0.18^{\mathrm{b}}$ & $4.71 \pm 0.21^{\mathrm{b}}$ \\
Lipid & $31.14 \pm 0.13^{\mathrm{a}}$ & $35.12 \pm 0.10^{\mathrm{c}}$ & $35.12 \pm 0.03^{\mathrm{c}}$ & $34.23 \pm 0.60^{\mathrm{b}}$ \\
Protein & $15.14 \pm 0.05^{\mathrm{a}}$ & $16.85 \pm 0.10^{\mathrm{c}}$ & $17.54 \pm 0.27^{\mathrm{d}}$ & $16.34 \pm 0.10^{\mathrm{b}}$ \\
Carbohydrate & $25.21 \pm 0.11^{\mathrm{d}}$ & $19.50 \pm 0.19^{\mathrm{a}}$ & $20.79 \pm 0.06^{\mathrm{b}}$ & $24.42 \pm 0.08^{\mathrm{c}}$ \\
Soluble dietary fiber & $0.54 \pm 0.12^{\mathrm{b}}$ & $0.54 \pm 0.08^{\mathrm{b}}$ & $0.59 \pm 0.06^{\mathrm{c}}$ & $0.37 \pm 0.06^{\mathrm{a}}$ \\
Insoluble dietary fiber & $20.56 \pm 0.16^{\mathrm{d}}$ & $18.40 \pm 0.11^{\mathrm{c}}$ & $16.66 \pm 0.13^{\mathrm{b}}$ & $16.16 \pm 0.05^{\mathrm{a}}$ \\
Resistant starch & $2.18 \pm 0.18^{\mathrm{a}}$ & $2.81 \pm 0.17^{\mathrm{b}}$ & $3.39 \pm 0.07^{\mathrm{c}}$ & $4.97 \pm 0.08^{\mathrm{d}}$ \\
\hline
\end{tabular}

Values are mean \pm SD. Different alphabet superscripts in the same row are significantly different $(p<0.05)$ 
rice flour contained $2.25 \%$ dietary fiber. $M$. arundinaceae flour contained $7.46 \pm 0.12 \%$ dietary fiber. In addition, flaxseed was also reported to contain $28 \%$ dietary fiber (Ganorkar and Jain, 2013).

\subsection{Physical properties}

Spread ratio is one of the characteristics that are important in determining the quality of cookies. The higher the spread ratio, the higher the desirable qualities. The value of the spread ratio decreased with a substitution of resistant starch. Hardness is related to the force required to break the cookies (Özboy-Özbaş et al., 2010). High protein gluten and egg-free cookies have a harder texture than the control cookies. Table 3 shows that the spread ratio cookies high protein gluten-free cookies have the smallest spread ratio $(\mathrm{p}<0.05)$ and significantly different from the control cookies. No significant difference was observed among the different formulations of high protein gluten and egg-free cookies. Spread ratio shows the capabilities of cookies to inflate (Olapade and Adeyemo, 2014). A higher spread ratio indicates the ability to inflate. Due to the lower spread ratio of high protein gluten and egg-free cookies, the shape of the cookies were restricted.

Texture results of the cookies are shown in Table 3. The hardness of the high protein gluten-egg free cookies can be related to protein content which requires more water to get right dough cookies. The results of this study were in line with the research that proves the cookie hardness increased with protein content from flour, especially above $10 \%$ (Fustier et al., 2009). Due to the higher protein content, the increased of its interaction occurs during development and baking (McWatters et al., 2003). The protein content in cookies also affects the product's development power. This is because the proteins are subjected to denaturation and thus, cookies become difficult to expand and turn hard. Starch granules without proteins will be easily broken, and the amount of water entered in the starch granules will be more so that the development of starch increases. The addition of margarine (fat) in the production of cookies will change the texture and flavor of the cookies. These fats can interact with starch granules and prevent hydration to increase the viscosity of the ingredients. The inhibiting mechanism is that the fat will form a layer on the outside of the starch granules preventing the penetration of water into the granules. A little water penetration will produce high gelatinization and will form cookies that are less inflated with denser texture which makes up the harder texture of the high protein gluten and egg-free cookies compared to the control cookies.

\subsection{Sensory properties}

Sensory evaluation showed that control cookies have the highest score than the high protein gluten and eggfree cookies in terms of color, aroma, flavor, texture (crispness) and overall acceptability $(\mathrm{p}<0.05)$. Based on Table 4, control cookies obtain the highest score (7.90 \pm 0.54$)$ in overall acceptability compared to the cookies made with RS3 M. arundinaceae flour. Cookies made with $10 \%$ RS3 $M$. arundinaceae flour had the best overall acceptability of $7.58 \pm 0.63$ among the cookies made with the high protein flour composition. While the cookies made with $12 \%$ of $M$. arundinaceae flour was favoured next and the least favoured was cookies made with $14 \% \quad M$. arundinaceae flour with scores of $7.23 \pm 0.69$ and $7.14 \pm 0.71$ respectively. It can be depicted that the increasing amount of RS3 M. arundinaceae flour decreases its level of acceptance and that the replacement of the wheat flour had impactly decreased the evaluation of a product by the hedonic panelist. (Yusufu et al., 2016).

Based on this research, it can be indicated that the high protein gluten and egg-free cookies made with $10 \%$ of RS3 M. arundinaceae flour is most preferred (Table 5). The developed high protein gluten and egg-free cookies will be health-benefitting particularly to those who are allergic to gluten and/or eggs and also contain resistant starch and high in dietary fiber.

\section{Conclusion}

High protein gluten and egg-free cookies made with $10 \%$ RS3 M. arundinaceae flour was the most accepted cookies. Despite having smaller spread ratio and higher degree of hardness than wheat flour made cookies due to the high protein content, the cookies can be developed in a functional food for people sensitive to gluten and/or eggs. It is recommended that future studies such as lowering the amount of RS3 M. arundinaceae flour used and substituting other ingredients, should be conducted to further improve the overall acceptability of the cookies.

\section{Conflict of Interest}

The authors declare no conflict of interest.

\section{Acknowledgments}

Authors would like to thanks to Directorate General of higher education for the research grants strategic competitive national with contract number 04/Penel./p. Stranas/UN 34.21/2017, 3rd April 2017. 
Table 3. Physical properties of wheat flour made cookies (WH-C) and high protein gluten and egg-free cookies with flaxseed (HP-GFC) of different formulations

\begin{tabular}{lccccc}
\hline Cookies type & Weight $(\mathrm{g})$ & Diameter $(\mathrm{mm})$ & Height $(\mathrm{mm})$ & Spread ratio & Texture \\
\hline WH-C & $1.51 \pm 0.02^{\mathrm{b}}$ & $33.99 \pm 0.13^{\mathrm{a}}$ & $3.51 \pm 0.03^{\mathrm{a}}$ & $9.69 \pm 0.09^{\mathrm{b}}$ & $12.24 \pm 0.25^{\mathrm{a}}$ \\
HP-GFC FI & $1.11 \pm 0.02 \mathrm{a}$ & $31.47 \pm 0.20^{\mathrm{b}}$ & $3.77 \pm 0.09^{\mathrm{b}}$ & $8.34 \pm 0.23^{\mathrm{a}}$ & $13.67 \pm 0.22^{\mathrm{b}}$ \\
HP-GFC FII & $1.11 \pm 0.02^{\mathrm{a}}$ & $31.50 \pm 0.26^{\mathrm{b}}$ & $3.79 \pm 0.07^{\mathrm{b}}$ & $8.32 \pm 0.24^{\mathrm{a}}$ & $13.84 \pm 0.12^{\mathrm{b}}$ \\
HP-GFC FIII & $1.11 \pm 0.02^{\mathrm{a}}$ & $31.48 \pm 0.21^{\mathrm{b}}$ & $3.79 \pm 0.09^{\mathrm{b}}$ & $8.32 \pm 0.24^{\mathrm{a}}$ & $14.02 \pm 0.14^{\mathrm{b}}$ \\
\hline
\end{tabular}

Values are mean \pm SD. Different alphabet superscripts in the same row are significantly different $(\mathrm{p}<0.05)$

Table 4. Sensory evaluation of wheat flour made cookies (control) and high protein gluten and egg-free cookies with flaxseed of different formulations

\begin{tabular}{lcccc}
\hline \multirow{2}{*}{ Characteristic } & \multirow{2}{*}{ Wheat cookies } & \multicolumn{3}{c}{ High Protein gluten and egg-free cookies } \\
\cline { 3 - 5 } & & FI & FII & FIII \\
\hline Aroma & $8.01 \pm 0.58^{\mathrm{c}}$ & $7.55 \pm 0.67^{\mathrm{b}}$ & $7.23 \pm 0.73^{\mathrm{a}}$ & $7.19 \pm 0.68^{\mathrm{a}}$ \\
Color & $7.93 \pm 0.67^{\mathrm{c}}$ & $7.40 \pm 0.77^{\mathrm{b}}$ & $7.21 \pm 0.74^{\mathrm{a}}$ & $7.06 \pm 0.79^{\mathrm{a}}$ \\
Taste & $7.89 \pm 0.50^{\mathrm{c}}$ & $7.56 \pm 0.73^{\mathrm{b}}$ & $7.29 \pm 0.78^{\mathrm{a}}$ & $7.29 \pm 0.78^{\mathrm{a}}$ \\
Crispiness & $7.82 \pm 0.55^{\mathrm{b}}$ & $7.71 \pm 0.56^{\mathrm{c}}$ & $7.14 \pm 0.65^{\mathrm{a}}$ & $6.98 \pm 0.75^{\mathrm{a}}$ \\
Overall aceptability & $7.90 \pm 0.54^{\mathrm{c}}$ & $7.58 \pm 0.63^{\mathrm{b}}$ & $7.23 \pm 0.69^{\mathrm{a}}$ & $7.14 \pm 0.71^{\mathrm{a}}$ \\
\hline
\end{tabular}

Values are mean \pm SD. Different alphabet superscripts in the same row are significantly different $(\mathrm{p}<0.05)$

Table 5. Formulation of the most prefered high protein gluten and egg-free cookies with flaxseed by panelist

\begin{tabular}{lc}
\hline \multicolumn{1}{c}{ Ingredient } & High protein gluten and egg-free cookies FI (g) \\
\hline Wheat flour & - \\
High protein gluten-free flour composition & 48 \\
Soy flour & 19 \\
Corn starch & 19 \\
$M$. arundinaceae flour & 13 \\
Tapioca flour & 15 \\
RS3 M. arundinaceae flour & 1 \\
RS3 C. tuberosus flour & 35 \\
Brown rice flour & $\mathbf{1 5 0}$ \\
Total gluten-free flour & \\
Other ingredients & 90 \\
Margarine & - \\
Egg & 10 \\
Flaxseed & 15 \\
Corn syrup & 2 \\
Salt & 75 \\
Cheddar cheese & 5 \\
Chocolate powder & 45 \\
Water &
\end{tabular}

\section{References}

Alcazar-Alay, S.C. and Meireles, M.A.A. (2015). Physicochemical properties, modifications and applications of starches from different botanical sources. Food Science and Technology, 35(2), 215236. https://doi.org/10.1590/1678-457X.6749

AOAC. (2005). Official Method of Analysis. 18th ed. Gaithersburg, Maryland, USA: AOAC

Barros, A., and Cosme, F. (2013). Allergenic Proteins in Foods and Beverages. Food Technology and Biotechnology, 51(2), 153-158.

Boettcher, E. and Crowe, S.E. (2013). Dietary proteins and functional gastrointestinal disorders. American Journal of Gastroenterol, 108(5), 728-736. https:// doi.org/10.1038/ajg.2013.97
Ciabotti, S., SIlva, A.C.B.B., Juhasz, A.C.P., Mendonca, C.D., Tavano, O.L., Mandarino J.M.G. and Gonçalves, C.A.A. (2016). Chemical composition, protein profile, and isoflavones content in soybean genotypes with different seed coat colors. International Food Research Journal, 23(2), 621629.

Englyst, H.N., Kingman, S.M. and Cummings, J.H. (1992). Classification and measurement of nutritionally important starch fractions. European Journal of Clinical Nutrition, 46, S33-S50

Filbert, K. and Sein, S.S. (2013). Gandum sebagai faktor pencetus DM tipe 1 pada anak. CDK-201. 40(2), 102 -106. [In Bahasa Indonesia].

Fustier, P., Castaigne, F., Turgeon, S.L. and Biliaderis, C.G. (2009). Impact of commercial soft wheat flour 
streams on dough rheology and quality attributes of cookies. Journal of Food Engineering, 90, 228-237. https://doi.org/10.1016/j.jfoodeng.2008.06.026

Ganorkar, P.M. and Jain, R.K. (2012). Flaxseed - a nutritional punch. International Food Research Journal, 20(2), 519-525.

Gisslen W. (2012). Professional baking. 6th ed. USA: John Willey and Sons.

Hall, C., Tulbek. M.C. and Xu, Y. (2006). Flaxseed. Advances in Food and Nutrition Research, 51, 9197. https://doi.org/10.1016/S1043-4526(06)51001-0

Lilia-Baby, Suman, K.T., Krishnan, S. and Indira, V. (2016). Effect of autoclaving and cooling on resistant starch formation in rice starch. Asian Journal of Dairy and Food Research, 35(2), 137142. https://doi.org/10.18805/ajdfr.v35i2.10722

Mamat, H. and Hill, S.E. (2014). Effect of fat types on the structural and textural properties of dough and semi-sweet biscuit. Journal of Food Science and Technology, 51(9), 1998-2005. https:// doi.org/10.1007/s13197-012-0708-x

Manley, D. (2000). Technology of Biscuits, Crackers and Cookies. 3rd ed., Cambridge: Woodhead Publishing Limited. https://doi.org/10.1201/ NOE0849308956

McWatters. K.H., Ouedrago, J.B., Resurreccion, A.V.A., Hung, Y.C. and Phillips, R.D. (2003). Physical and sensory characteristics of sugar cookies containing mixtures of wheat, fonio (Digitaria exilis) and cowpea (Vigna unguiculata) flours. International Journal of Food Science and Technology, 38(4), 403 -410 . https://doi.org/10.1046/j.13652621.2003.00716.x

Nugraheni, M., Lastariwati, B. and Purwanti, S. (2017). Proximate and Chemical Analysis of Gluten-free Enriched, Resistant Starch Type 3 from Maranta arundinacea Flour and its Potential as a Functional Food. Pakistan Journal of Nutrition, 16(5), 322-330. https://doi.org/10.3923/pjn.2017.322.330

Okaka, J.C. (2009). Handling, storage and processing of plant foods. 2nd ed., p. 132. Enugu, Nigeria: Academy Publishers.

Olapade, A.A. and Adeyemo, A.M. (2014). Evaluation of Cookies produced from blends of wheat, cassava and cowpea flours. International Journal of Food Studies, 3, 175-185. https://doi.org/10.7455/ ijfs/3.2.2014.a4

Özboy-Ozbaz, O., Şeker, I.T. and Gokbulut, I. (2014). Effects of Apricot Kernel Flour and Fiber-Rich Fruit Powders on Low-Fat Cookie Quality. Turkish Journal of Agricultural and Natural Sciences, Special Issue 1, 1326-1332
Robertson, M.D., Bickerton, A.S., Dennis. A.L., Vida, 1.H. and Frayn, K.N. (2005). Insulin-sensitizing effects of dietary resistant starch and effects on skeletal muscle and adipose tissue metabolism. American Journal of Clinical Nutrition, 82, 559567. https://doi.org/10.1093/ajcn/82.3.559

Tsatsaragkou, K., Gounaropoulos, G. and Mandala, I. (2014). Development of gluten free bread containing carob flour and resistant starch. LWT-Food Science and Technology, 58(1),124-129. https:// doi.org/10.1016/j.lwt.2014.02.043

Uhlman, J. and Schumacher, J. (2014). Sensory and Objective Evaluation of Pumpkin Bars using Ground Flaxseed or Sweet Potato Baby Food as Egg Replacers. International Journal of Advanced Nutritional and Health Science, 2(1), 89-97. https:// doi.org/10.23953/cloud.ijanhs.151

Yusufu, P.A., Netala, J. and Opega, J.L. (2016). Chemical, sensory and microbiological properties of cookies produced from maize, African yam bean and plantain composite flour. Indian Journal of Nutrition, 3(1), 122

Zoulias, E.I., Piknis, S. and Oreopoulou, V. (2000). Effect of sugar replacement by polyols and Acesulfane-K on properties of low-fat cookies. Journal Science Food Agriculture, 80, 2049-2056. https://doi.org/10.1002/1097-0010(200011) 80:14<2049::AID-JSFA735>3.0.CO;2-Q

Zucco, F., Borsuk, Y. and Arntfield, S.D. (2011). Physiscal and nutritional evaluation of wheat cookies supplemented with pulse flours of different at particle sizes. Food Science and Technology, 44(10), 2070-2076. https://doi.org/10.1016/j.lwt.2011.06.007 